\title{
Assessment of Forest Management Institutions and Their Initiatives in the Rainforest Communities of Cross River State, Nigeria
}

\author{
Anim O. Ajake \\ Dept. of Geography and Environmental Science, University of Calabar, P.O.BOX 3667, Calabar, Nigeria \\ Tel: 234-803-666-9251Ｅ-mail: ajakeunical@yahoo.com
}

R. N. C. Anyandike

Dept. of Geography, University of Nigeria, Nsukka, Nigeria

Received: October 25, 2011 Accepted: November 8, $2011 \quad$ Published: March 1, 2012

doi:10.5539/jgg.v4n1p257 URL: http://dx.doi.org/10.5539/jgg.v4n1p257

\begin{abstract}
This study evaluated forest management institutions and their initiatives in the rainforest communities of Cross River State. Data were collected through questionnaire survey and participatory research methodologies. Data generated were analyzed using descriptive statistics and one-way analysis of variance (ANOVA). The result of the analysis reveals that community forest management institutions and their initiatives have significant influence on forest ecosystem management than other institutions such as government and non-governmental organizations. The study discovered that community forest management institutions were rated very high in terms of sustainable harvesting techniques, encouragement of forest reservation and monitoring of forest management programmes among others. The other institutions were rated low in their influence on forest management. Based on these findings, the study suggested some remedial measures that will ensure sustainable forest management in the area, such as partnership forest management, alternative income generation opportunities and holistic consideration of the forest lands during management.
\end{abstract}

Keywords: Forest, Institutions, Initiative, Sustainability, Management, Effectiveness, Indigenous

\section{Introduction}

The rainforest ecozone remain the source of supply of forest resources to the rural population (Ajake, 2008). However, the need to wrest a living from the available natural resources has in turn resulted in environmental degradation, which has adversely affected vis-a vis reduction in diversity of fauna and flora species. According to Davey et al. (2003), conserving forest resources has become an issue of increasing priority and urgency in recent years. This is obvious because several studies have reported the severe consequences of forest resource depletion to the rural population (Ajake, 2008; FAO, 2007). Although deforestation is the main cause of resources depletion especially in the Tropics (Waggener, 2004), but National Research Council (1993) observed earlier that the consequences cannot be assessed precisely and the magnitude of the interrelated issues such as social and economic impacts are difficult to determine. However, the option available for tackling the issues and to slow down the decline in the forest ecosystem and biological diversity are limited and discouraging (Gomez -Pompa and Burley, 1991).

In the past thirty years, there has been increased concern at both national and regional levels about the declining condition of forest resources. This concern has prompted Government of various nations, Non-governmental Organizations (NGOs) and rural communities to enact a number of laws to protect specific species of the forest ecosystem. The conservation of the diversity of natural forest is needful, since it maintains all the essential functional components of the ecosystem in situ (Kemp et al., 1993) and constitutes the basis for the socio-economic livelihood of the rural people. Natural forest management can be a vehicle to prevent on commitment the forest, biodiversity, climate change and desertification as well as contributing towards achieving the Millennium Development Goals (FAO, 2007).

Efforts in managing forest resources have increased tremendously across the nations but the future management of the forest landscape is under debate (Schreckenberg and Hadley, 1991) and sustainable forest management is 
often seen as experimental approaches adopted without achieving the goals of management. FAO (2007) reported that forest landscape restoration bring people together to identify, negotiate and implement practices that restore an optimal balance among the ecological, social, cultural and economic benefits of forests and trees within the broader pattern of land uses. If involves practical approaches that do not try to re-establish the pristine forests of the past. The goal is to adopt holistic approaches that restore the function of forests and trees and enhance their contribution to sustainable livelihood and land uses.

Forest management initiatives are ideas, plans and practices that are targeted at achieving management goals. These initiatives vary from region to region and from one form to the other. Management initiatives can be in the form of forest laws and regulations, forest harvesting techniques, advocacy programmes, restrictions, empowerment, monitoring programmes, capacity building among others. FAO (2007) noted that the development of forest related voluntary guidelines is key to many international agencies work in management. They vary in scope and level from detailed operational practice to broader policy guidelines and from regional to global. The most successful of the initiatives has one thing in common: they were developed by a broad spectrum of stakeholders representing government, the private sector and civil society institutions. Forest management initiatives provide guiding principles on forest use and management. Experience has shown that successful forest management in most countries of the world stemmed from the national Government down to the communities. Ashish et al. (1998) observed that from standardized policies and programmes initiated by centralized and urban-based agencies, a slow but definite shifting is taking place towards decentralized, site specific and community based initiatives to forest management. Local schemes have potentials to realize the three interconnected pillars (economic, social and environmental) of sustainable management (Rauflet and Barragan, 2006). Increased economic value, created from improved resource management, combined with local participation in decision making and benefit sharing, would increase the incentive to manage forest in a sustainable way. Scot (1996) contends that 'modernist' centralized management schemes has resulted to the weakening of local communities and deprived them of incentives to manage forest well.

Recent publications have brought about the world concern toward participatory conservation models (West and Brechin, 1991; Western and Wright, 1994 and Kothani et al., 1996) investigations have shown the reasons for community involvement in conservation such as frequent interaction with the areas and species sought to be conserved (Borri-Feyerabend, 1996); Conflict and physical clashes between people and forest officials (Pande et al., 1989); considerable wildlife still exists outside protected areas under local communities control, insufficient staff, underfunding, ill trained staff and ill-equipped to handle myriads of threats; declining political support for conservation (Ashish et al., 1998); ill-fated assumption that conservation is only possible through exclusion of human activities (Saberwal, 1996); sharing of responsibilities, in-depth knowledge and experience of wildlife and habitat, and demand for greater participation in decision making and the control of the resources which sustain their lives and livelihoods (Ashish et al., 1998). The local people are knowledgeable about their natural forest ecosystem. The knowledge and skills developed for many years to adapt to and manipulate their land, flora and fauna constitute invaluable resources for sustainable forest management (Glimire and Pimbert, 1992 and WWF 1993).

According to Headley (2003), local forest management committee were established across rural communities as an instrument for local people to be involved in utilization and management of nearby forest reserves. In China, more than 60 percent of rural forest is under the control of village economic co-operative (Bruce et al., 1995). Community participation in forestry is yet to receive recognition in Nigeria, but Bisong (1998) in Cross River State identifies some traditional institutions in rainforest communities that make rules and regulation based on their knowledge systems to regulate the collection of forest products and ensure sustainability.

In some countries, changes in Government policies have affected the local people participation in forest use and management. For instance, in Srilanka, Ashish, Anuradha and Pathak (1998) report that the National Forest Policy and the forestry sector master plan in 1995 adopted and recognized the role of local resource users and NGOs in forestry management. While the master plan for forestry sector in Nepal in 1988 empowers local users to manage forests to provide total benefits from such management to the community, and the role of forest officials as extension agents rather than a policing force (Joshi, 1996). The forest policy statement of Pakistan in 1991 stresses the participatory approach and integrated management of natural resources. In India, the national forest policy of 1988 linked conservation to meeting the basic needs of the people, and maintaining the intrinsic relationship between forest and tribal and other forest dependent people by protecting customary rights. Cameroon, Tanzania, Guinea and South Africa forest policies have been reviewed with the mechanism for devolution of forest management to local communities (FAO, 1999). In some nations, forest policies have recognized the historical land claims by local people. Brazil, Columbia (NRC, 1993) and Philippine (FAO, 1999) 
have recently recognized the claims of indigenous people to large forest areas and have given them greater responsibility for managing these areas. Philippines in 1997 promulgated the indigenous people's right act that disposes forest to communities and individuals.

In Nigeria, forest management initiatives vary from one state to another. Ogar (2001) earlier remarked that Nigeria National forestry policy is yet to be promulgated. However, states profess policy statements which are slightly different from the National forest policy, but are subscribed to the concept of sustained yield and maximization of socio-economic benefits. Government continue to retain absolute decision making power, including the power to decide and approve forest management plans and determine the species to be harvested as well as how much has not been achieved. In addition, Government decides the price of species harvested, markets of products and how benefits are shared. There are no legal provision that protect the traditional rights of indigenous people in spite of their involvement in ensuring sustainable forest resources use and management. However, in Cross River State, various Forest management initiatives are recognized such as Government, Non-governmental Organization and indigenous people practices. Experience has shown that their level of commitments and achievements are not known. This explains why government institutions are still believed to have done much, in spite of the significant performance of Non-governmental Organizations (NGOs) and indigenous people in forest resources management. Evaluation of the activities of various management institutions is absent. There is therefore scarcity of data about their activities in forest management in Cross River State, but few studies focused on the utilization and management of the forest. Even though, various management approaches are recognized in forest management in the study area, their continuous evaluation to ascertain their level of effectiveness or performances are totally non-existence. To avoid this unwholesome situation, this study seeks to evaluate forest resources management institutions and their initiatives based on the people's perception in the rainforest communities of Cross River State, Nigeria.

\section{Study Area}

Cross River State is located in South Eastern Nigeria. The area lies between longitudes $7^{\circ} 40^{\prime \prime}$, and $9^{0} 50^{\prime \prime}$ East of the Greenwich meridian and latitudes $4^{\circ} 40^{\prime}$, and $7^{\circ} 00^{\prime}$ "North of the equator. It covers an area of approximately $23,074.43 \mathrm{~km}^{2}$ (Figure 1). The area is within the equatorial region with mean monthly temperature of between $24.2^{\circ} \mathrm{C}$ to $27.4^{\circ} \mathrm{C}$, and average annual rainfall of between $2000 \mathrm{~mm}$ to $3500 \mathrm{~mm}$. This climate support forest growth which constitute the remaining part of the rainforest in Nigeria. The rainforest has been expansively exploited, but significant portion is still geographically spread across Akamkpa, Ikom, Biase, Yakurr, Obubra, Boki, Obudu and Obanliku local government areas of the study area (Table 1).

Although, a significant part of the area is still covered with the high forest, it is apparent that most areas are undergoing severe degradation. The increasing degradation of the forest ecosystem and the risk of forest resources extinction have prompted the intervention of different forest management institutions such as government, Non-governmental and community. According to Ajake (1998) the intervention of these institutions and their initiatives was to preserve, maintain, restore and enhance sustainable utilization of resources in order to reduce pressure on the remaining primary forest in Nigeria.

Cross River State gazette and community protected forest areas covers about 921,706hectares (Ajake, 2008). This figure is distributed between government reserve and community protected forest. The government forest areas (National park covering Okwango and Oban division and forest reserves) has area coverage of 712,591.86 hectares representing 77.31 percent while the community protected forest area is about 206,290.25 hectares representing 22.69 percent (Table 2). Although government forest lands are large, they are undergoing severe degradation due incessant human activities.

\section{Research Method}

In order to obtain correct information about the evaluation of the various forest management institutions and their initiatives in the rainforest communities of Cross River State, data were collected in 2010 with the aid of household questionnaire survey and participatory rural appraisal methods. The questionnaire was considered more effective due to it comprehensiveness and the potential to suggest specific measurable indicators. The survey was carried out on 1,457 household heads that represent 50 percent of the total household number of 2,914 in eighteen sampled communities spread across nine local government areas which were purposely selected due to their direct interface with the natural forest areas (Table 2) under various management institutions of government, community and non-government organizations. The sampled villages were Agbokim, Ajassor, Akparabong, Okuni, Abo Ebam, Odonget, Iyamitet, Orimenkpang, Agoi Ekpo, Ibami, Ibogo, Idoma, Iko Ekperem, Iwuru central, Bayatang, Okorshie Bendi II and Busi I. 
The questionnaire captured questions on the type of types, resources gathered, type of management institutions, initiatives and enforcement of forest management decision. The questionnaire indicated questions that used the weighing system to assess effectiveness of forest management institutions and their initiatives. This system follows closely that of Udofia (2006) by a respondent attaching 5 to first order effectiveness to the least order effectiveness. Having weighted the effectiveness, the product of the number of household heads was summed for each sampled village to give the effectiveness score of forest management institutions and their initiatives. The higher the scores, the more effective is the institution and vice versa.

The participatory rural appraisal methods such as the checklist, semi structured interviews, participatory observation and group discussion were used to generate data that were not adequately covered by the questionnaire survey. The semi-structured interviews were guided by the checklist that show, pre-determined issues such as type of forest, forest area coverage, use patterns, forest resource status, forest management institutions and their initiatives etc. The interviews were on village group discussion, key informants, specialist group, elders, chiefs, youth leaders, civil servants, forest workers and individuals to generate representative knowledge of the community and their relationship with forest ecosystem. Direct observation was also used to enable us determine the distance to the natural forest, forest harvesting techniques, management practices and other land use patterns in the area.

\section{Results and Discussion}

The analysis of data was based on the weighing system of household heads by scoring effectiveness level of various institutions and their initiatives. The scores as earlier mentioned ranges from one to five (1-5), where five represents the first order effectiveness or high performance and one indicate least order effectiveness or low performance. The mean sum of these weights was presented in percentages. Thereafter, the one-way analysis of variance (ANOVA) was used to isolate the management institutions that yielded more benefits and effectiveness in forest management in the study area. The findings are presented accordingly.

\subsection{Effectiveness of Forest Management Institutions}

The complexity of the forest ecosystem and the severe consequences created by its degradation has attracted the commitment of various institutions for sustainable management. The study identified three rain forest management institutions in the area such as government, community or traditional and non-governmental organizations (NGOs) (Table 2). These institutions were recognized by the people being instrumental to various sustainable utilization and management for several years.

The household questionnaire survey was used to assess the level of effectiveness of these institutions across the eighteen study settlements. The assessment was not based on ignorance and prejudice of all the identified institutions in the study area. The result shows that community or traditional forest management institutions attracted a higher mean score of 64.83 representing 70.95 percent. This was closely followed by government institutions with mean score of 18.66, while Non-governmental organizations (NGOs) activities have 7.83 (Table $3)$. The analysis revealed that community forest management was considered by the people to have created more impacts on the management of forest resources than government and non-government organizations activities in the study area. It was discovered two forest management institutions have different forest types in which they are in control. For instance, the community management institutions focused on community forests, while government institutions are restricted to forest reserves, national park and regulation of timber flow from community forests. The non-governmental organizations efforts are supplementary to government and community forests (Table 2 ).

Community institutions and their initiatives are people oriented forestry activities based on their knowledge systems. The decisions and rules for forest regulations and management are principally taken by the indigenous people. But government management institutions and their initiatives were imposition of ideas and techniques on the people. The study observed that such impositions were resisted in most study communities.

\subsection{Evaluation of Forest Management Initiatives in the Area}

As earlier mentioned, forest management initiatives are ideas, plans and practices that are targeted at achieving the management goals of the forest institutions. The questionnaire survey and participatory assessment of the study area revealed several forest management initiatives where the three forest institutions have adopted to ensure sustainable forest ecosystem management. These initiatives include forest law/regulation, advocacy, restrictions or reservations, harvesting techniques, empowerment, capacity building, monitoring programmes among others (Table 3). The findings presented in Table 3 reveal significant disparity in the level of effectiveness of forest management initiatives. Out of 8 initiatives identified, sustainable forest harvesting 
practice has the highest mean score of 98 representing 22.69 percent. This is followed by Advocacy with 70 mean score representing 16.20 percent and forest law/regulation (15.56 percent). Monitoring of forest management programmes received the least mean score of 25 representing 5.79 percent. The consideration of sustainable forest harvesting techniques was an indication that the three institutions recognized forest exploitation as the main factor for forest ecosystem degradation. Forest exploitation techniques vary from region to region depending on several factors. The main harvesting techniques in the area are selective and total exploitation. Ajake (2009) identified several techniques among the indigenous people in Cross River State such as selective felling, plucking, peeling, picking among others. These techniques were adjusted by the people as effective sustainable practices in the area. The study further shows that sustainable harvesting initiatives are mostly encouraged by the community forest management institutions and government agencies. These attracted 40.83 percent and 36.61 percent respectively (Table 3 ). The non-governmental organizations are seen as playing supplementary function to the other institutions.

Forest management advocacy were educational awareness programmes adopted by non-governmental organizations to ensure sustainable forest management. The institution attracted 51.43 percent; while the community institutions have 31.43 percent score (Table 3). Other initiatives which promote and encouraged effective forest management in the area included afforestation programmes and silvi-cultural practices. Although forest monitoring initiative received the least mean score of 25 representing 5.79 percent (Table 3 ), but the study indicated that traditional or community institutions were disserved as playing the major role in encouraging indigenous people to monitor the different changes in the forest ecosystem. This attracted 20 mean score representing 80 percent in comparison with the activities of government institutions and non-governmental organizations. Economic empowerment was another area where non-governmental organizations and community institutions have influenced. The rural people are given incentives such as: - seedlings, working equipments and funds to assist in their local productive activities, this is intended to reduce pressure from the primary forest.

On aggregate, the community institutions were discovered by the respondents to have effectively influenced the eight forest management initiatives than the other two institutions (Table 3). This institution attracted 25.25 mean score representing 46.76 percent above government institution with 15 mean score representing 27.78 percent, while the NGOs attracting 13.75 mean score in that order (Table 3). This analysis indicates the level of commitment by indigenous people in the management of forest in which they considered as their home and work place. In addition, the analysis also shows that, government or the state institutions are weak in ensuring the implementation of policies and programmes targeted at forest management. Rather, the non-governmental organizations (NGOs) concept which is a recent, phenomenon is almost taking over the responsibility of government in forest management in the study area. Detailed analysis shows that, while the NGOs are involved in forest management advocacy, empowerment of the forest people, and capacity building, indigenous people are imposing restrictions in the use of forest, encouraging the implementation of forest law and regulation as well as monitoring the changes in the forest ecosystem.

\subsection{Analysis of Forest Management Institutions and Their Initiatives}

In order to establish the difference among three Forest management institutions and confirm their effectiveness and sustainability, One-way analysis of variance was employed. The results of the analysis are presented in Table 4. The analysis of variance produces an F-ratio of $25.36>3.32$ (tabulated value) at 0.05 level of confidence. Thus, a statistical significant difference in the effectiveness of forest management institutions such as Government, non-governmental organizations and community was observed. This result supports the earlier assertion that forest management institutions and their initiatives have significant impacts on effective and sustainable management of forest resources than others. The findings indicate that apart from efforts of government and non-governmental organizations in promoting forest management in the rainforest, the host communities whose socio-economic livelihood depends on the forest are significantly involved in the management of the remaining rainforest. The participatory rural appraisal techniques employed by the study revealed some attractive details about forest management initiatives in the area.

The study observed that local people in the area were naïve about the government initiatives in forest resources management. Community informants and government forestry workers also indicated that government initiatives are strictly narrowed to reserve forests, thus undermining community lands. These findings are in agreement with Balogun (1994) who stated that the local communities are excluded from the management of large areas of forest which are designated as forest reserves and are exploited by large concessionaries. The main interest of government was to ensure sustainable harvesting of timber resources from the reserves. The study discovered that government used the instrument of forestry law to regulate the harvesting of timber resources from the reserved forest and community forests. For instance, the regulation of timber resources was through the use of 
forestry tariff. Tariffs were charged based on the grade of timber. 'Grade A' timber such as Afzelia spp (apa), Baillonella toxisperma (Mimosup), Diospyros spp (Ebony) etc with a diameter of $21.1 \mathrm{~m}$ are valued at N1,800 and N4,000 during 1994 and 1999, whereas in 2005 and 2006, the same species increased in value to N6,000. According to Ogar (2001), low tariffs increase the rate of deforestation since the cost of using the forest is low. But, if the tariff is high, it encourages illegal exploitation of the forest products. These tariffs are revenue base for the government. Timber extracted from community forests is also under the tariff regime. This constitutes the basis of royalty payment to communities yearly by the government.

The forest law inhibits hunting of certain wildlife animals that are considered to be extinct in the forest ecosystem. Such animals include elephants, lions, tigers, gorillas, chimpanzee etc. The study observed that the Forestry workers (Government Agents) have the mandate to enforce forestry legislations and monitor the sustainable harvesting to the negligence of the indigenous people who are the custodian of the forest. Meanwhile the killing of wildlife animals under preservation attracts a penalty of imprisonment when convicted by the court of law or a fine determined by the judge following the provision of forest law. In addition, government gives permit to timber extraction companies with the intention of controlling excessive exploitation. The study further observed that there is increased illegal timber exploitation, poaching of extinct animals, encroachment on forest reserves by farmers and hunters, and illegal harvesting of non-timber forest products from the National park which was designated protective or preservation of flora and fauna of the area. This was attributed to lack of effective forestry legislation, monitoring of forest harvesting activities and conflicts between government and local communities in forest management.

Furthermore, the study identified several Non-Government Organizations operating in the area. These organizations partner with community and government agencies (Table 3) for advocacy of sustainable use and management of forest resources to support the needs and priorities of the local people. They played a major role in implementing some forestry programmes and specific activities inherent in the sector. In table 2 the findings indicated that 8.58 percentage scone by the study population confirmed that non-governmental organizations have created positive impacts in the management of forest resources in the area. Although, the concept of non-governmental organization was recent in the area, the programmes and activities have caused remarkable changes in forest management. Further investigation revealed that apart from preservation and conservation activities, NGOs in the area are involved in intensive education and enlightenment campaign against further depletion of forest resources, capacity building through training and provision of micro-credit to the local people, and establishment of pilot projects in some communities such as Iko Ekperem, Okorshie, Okuni, Mbe mountains, Afi mountains etc. The PRA study discovered a number of Non-governmental Organizations that were into partnership with the Cross River State Forestry Project to conserve the forest. These NGOs carried out their activities based on their specific objectives in the study area. The most remarkable are Worldwide Fund for Nature (WWF), Nigeria Conservation Foundation (NCF), Wildlife Conservation Society (WCS), Fauna and Flora International (FFI), Development in Nigeria (DIN), Pandrillus, Cercopan, Living Earth., One sky, Sustainable Practice of Agriculture in Critical Environment (SPACE), RUENPROUT, NGO Coalition in Environment (NGOCE), Directorate for International Development (DFID), Canadian International Development Association, European Union and United States Forest Service.

The last four Non-governmental Organizations are international donor agencies who are supportive of the conservation initiatives of the study area. For instance, the Directorate for International Development (DFID) in 2000 and 2001 carried out a participatory landuse planning in several rural communities including Okuni, Abo Ebam, Iko Ekperem and Okorshie. The study also found that the pilot projects of developing forest plantations have contributed in reducing pressure from primary forest in most sampled communities. These plantations of timber and non-timber forest species have yielded significant benefits to the indigenous people. The worldwide Fund for Nature (WWF), Nigeria Conservation Foundation and Living Earth are committed in advocacy on the need to conserve and protect the remaining rainforest for purpose of ensuring sustainability in the use of forest resources. In 2006, the Wildlife Conservation Society and Nigerian Conservation Foundation hosted a workshop and conference in Calabar organized and founded by WWF, African Apes programme, the United States Fish and Wildlife Service, Fauna and Flora International and Wildlife Conservation Society on gorilla's conservation in Mbe mountain, Afi mountain, Afi mountain and others. The recommendations of this workshop and conference were adopted for the protection of the Cross River gorillas in terms of socio-ecology, ecotourism and gorilla habitation, the development of trans-boundary protected areas, legislation education and awareness, community conservation and enclave management as well as monitoring and research needs. Further investigation shows that apart from introducing improved species of plants and animals, monitoring of conservation activities in the forest, they arrest and prosecute offenders. Skills development and training on 
sustainable harvesting methods were also part of pilot studies on the changes in the forest ecosystem and development of small-scale infrastructures for educational advancement in the study communities. Ubi (2007) confirmed that environmental education has impacted positively on the youths. This was reported to have caused a change in attitudes of people towards forest ecosystem.

The study observed that community initiatives are borne out of the people cultural practices and their knowledge systems which they have acquired from the forest for a long time. It was discovered that, the harvesting of forest products, reservation of forest lands, tree planting, fallow practices and the use of traditional institutions to monitor the changes and regulate forest use were considered highly sustainable than other practices. This was obvious because they have greater impacts in terms of the benefits derivable to the people and the reduction of pressure from the primary forest ecosystem.

Further investigation show that forest management initiatives differ from one institution to another (Table 4). This is due to the level of institutional commitment in enforcing and implementation of such initiatives. Semi structured interviews, key informant discussion, group discussion with chiefs, elders and forestry workers revealed an interesting picture of the disparity. The findings are presented accordingly.

i. Forest law and regulation: The study reveals that diverse systems of rules and regulations exist in the use of forest products in the study area. For instance, government institution formulates policies that designate forest land into reserves and national park (Table 2). The PRA study observed that most reserves are leased to concessionaries who exploit timber resources on the basis of payment of forestry tariffs. We discovered that government used the instrument of forest law to regulate the harvesting of timber resources from reserve forests and community lands. Tariffs application on various timber species was considered earlier in this work. Forest law also inhibits hunting of certain wild animals that are considered extinct. Such animal includes Elephants, Lions, Tigers, Gorrillas and Chimpanzee. The study discovered that the enforcement of forest legislations is mainly carried out by agents of government (forest workers). It was further discovered that these agents are ill-equipped and cannot confront the challenges of sustainable management of large forest estates of government via-a-vis increased encroachment and poaching, especially in the Cross River national park area. In the same vein, community institutions make rules and regulation in managing all types of products harvested from community forest land areas. These rules and regulations emphasized the various rights of the people to utilize the forest ecosystem. For instance, all indigenes have right to harvest timber and non-timber forest products. Community regulations tend to be directed at levying non-indigenes who exploit forest products and controlling exploitation in order to maintain price levels and income from community activities. The application of community forest law is based on the different measures adopted to punish defaulters. The study discovered that certain forest products such as timber, bush meat, cattle stick, sleeping mat, chewing stick, bush mango, oil palm, cane rope, etc are under strict regulation and management, while other food based resources such as mushroom, mimosup seed/oil, hot leaf among others are slightly regulated. Rules concerning timber harvesting focus on restriction of non-indigenes exploitation of the forest and ensuring that communities collect agreed revenues. Breach of community agreement in the harvesting of product from community forest attracts penalty which varies from village to village. In addition, the study discovered that non-indigenes are not given free access to harvest or exploit non-timber forest products from their state of occurrence; rather they buy the products from the indigenes after proper registration with the host community. Apart from timber, forest products of 'plants origin' are not permitted to be uprooted or cut down during harvest. The occurrence these unwholesome practices attract sanctions as observed across the study communities. However, hunting is only restricted in sacred forest lands. The study further observes that the implementation of community forest policies was the responsibility of all indigenes of that community.

ii. Forest Harvesting Techniques: The PRA study discovered that government, community and non-governmental organizations are copiously committed in ensuring sustainable harvesting practices (see also Table 4). Community institutions encourages selective harvesting through techniques such as picking, peeling, plucking and felling; while the government (Forestry Department) guides forest concessionaries in selective harvesting of timber resources using the chainsaw machines. Also, government gives permit especially to timber operating companies in order to control indiscriminate exploitation. The non-governmental organizations are organized training programmes on new techniques in sustainable forest resources harvesting.

iii. Forest Advocacy: Forest resources management advocacy is a recent phenomenon in the area. It is an activity structure mainly associated with non-governmental organizations (Table 4). There are involved in workshops, seminars, radio and television programmes, drama in primary and secondary schools, village 
consultations etc. These activities are used to educate the people on the need to protect their rights and manage forest resources available to them. On the other hand, community institutions assist the NGOs in ensuring that the message of environmental education is transmitted to the people in their own native language using town criers and traditional dances on specific days of the week. Periodic meetings in village square are organized for youths, women and elders for the purpose of information dissemination. The actions of government institutions are still yet to be felt by the people. In most cases, government came under the umbrella of the non-governmental organizations to promote forest management. This was reported by some forestry workers during the study. It was further discovered that periodic radio and television announcements, commentaries and broadcast were activities organized by government institution.

iv. Forest Reservation: Both community and government institutions are observed to be involved in this initiatives (Table 4). A group discussion with elders and specialist groups indicated that indigenous people utilizes the natural forest ecosystem for its cultural qualities. Most forest areas across the sampled communities are preserved for traditional purposes such as medicinal value, cultural initiation ceremonies, idol worshiping and holding secret meetings. Traditional war dances are used to protect such forest areas. The most effective war dances used for forest protection are 'ekpe society' in Iwuru Central, Idoma, Iko Ekperem, Ibogo, Ajassor, Agbokim, Akparabong, Okuni and Orimenkpang sampled communities. 'Obam war dance' is the instrument of forest protection in Agoi Ekpo and Ibami, while the 'Ebranbit war dance' is dominant in Iyametet and Odonget communities. In some study communities (Okuni, Iyametet and Odonget), the forest was preserved and used as a healing home for different sicknesses. The study further observed that government institutions focuses on the preservation of Cross River national part forest area (Table 2) which constitute the remaining natural forest ecosystem in Nigeria. However, accelerated encroachment due to weak institution was noticed especially around forest communities having interface with the park.

v. Capacity Building: Further investigation shows that capacity building was a critical responsibility of non-governmental organizations (Table 4). They are involved in training of forest people to acquire skills that can engage them on economic activities outside forest exploitation. In order to ensure that such skills are sustained, micro-credit loans was provided to assist the indigenous people in animal husbandry (pig, goats, poultry, snail etc) and craft work such as weaving of sleeping mats, making of roof mats etc. Sustainable forest harvesting skills were also the focus of NGOs across the study communities. The two other institutions (government and community) were observed to be supplementing the activities of the NGOs.

vi. Monitoring of Forestry Programmes: Several interviews conducted across the study communities revealed that indigenous people who lived and worked in the forest were considered as the people who keep close watch (forest police) on the changes and activities in the remaining forest areas of Cross River State. At various communities' levels, age groups, specialist groups, village committees, elders and forest management committees were actively supervising forest programmes or activities. They were reported as giving early signals on the changes in terms of forest degradation. Few cases where government agents or workers were seen in forest monitoring, it was reported that, they were along major roads, settlements and forest management offices.

Finally, the study observed that there is increased illegal timber exploitation, poaching of extinct animals, encroachment on forest reserves by farmers and hunters, and illegal harvesting of non-timber forest products from the national parks. This was attributed to lack of effective forestry legislations, monitoring of forest harvesting activities and conflicts between government and community institutions in forest management areas.

\section{Conclusion and Recommendations}

The forest ecosystem presents the basis for sustenance of the people in Cross River State. Increasing deforestation has greatly affected them. Therefore, forest resources should not be undermine in the livelihood security of the rural population. Even though, the Government or State management institutions and Non-Government Organizations (NGOs) are more scientific in their forest management practices, the community management initiatives should not be undermine. This is because their management initiatives are stemmed from their long experience of the forest ecosystem. Their knowledge systems are vital for sustainable forest management practices in the area. The Government or State initiatives through the instrument of forest law deprived indigenous people from the use of forest resources especially the National Parks and forest reserve areas. This difference in management initiatives has generated conflicts in most of the study communities, 
vis-à-vis, indiscriminate and illegal attacks on the remaining reserved rainforest areas (National Park) in Cross River State.

The study recommended that community institutions and their initiatives can be encouraged and strengthened with the support of the state forest management institutions and non-governmental organizations. In addition, partnership forest management, alternative income opportunities and holistic consideration of the forest ecosystem management should be encouraged in Cross River State. Sustainable forest management goals and strategies would be widely accepted and supported locally and internationally where they fully integrate, and are seen to enhance the welfare and living conditions of the population who are highly dependent on forest resources.

\section{References}

Ajake, A. O. \& Omoogun, A. (2010). Re-invigorating indigenous forest exploitation techniques for sustainable environmental management in Cross River State. Ghana Journal of Educating and Teaching, 9, 162-174.

Ajake, A. O. (1998). Women in forest resource use and management in Akamkpa Area of Cross River State. unpublished M.Sc. Thesis. Calabar: University of Calabar,.

Ajake, A. O. (2008). Exploitation and management of forest resources in Cross River State, Nigeria. Unpublished Ph.D Thesis. Nsukka: University of Nigeria.

Ashish, K. A., Nurandhar, R. U., \& Pathakin. (1998). Community-based conservation: issues and prospects. In Ashish, K., Anurandha, R.V., Freneja, B. and Pathak, N. (eds), Communities and Conservation of Natural Resources in South and Central Asia, (pp 25-57). New Delhi: Sage publications.

Balogun, P. (1992). Social and economic issue of Forestry in Cross River State. Working paper, 16, 1-49.

Bisong, F. E. (1993). Farming systems, Human Ecology and Natural Resources Conservation in Cross River State. (pp 15-85). Calabar: FDD/CRSFP.

Bisong, F. E. (1998). Community Institutions and Resource Management: Resilence and Adaptation of traditional mechanism for sustainability. Proceedings of Annual International Conference of Community Development and Society, Kanda City, Missouri.

Davey, S. M., Hoare, J. R. \& Rumba, K. E. (2003). Sustainable forest management and the Ecosystem Appraisal: an Australian perspective UNASYLVA, 64, 214/215.

Dunn, R. M., Otu, D. O. \& Wong, J. G. (1994). Reconnaissance inventory of high forest and swamp Forest Areas in Cross River State. Workshop paper for Cross State Forestry Project, Calabar: FDD

FAO. (1999). State of the World's Forest. Rome: FAO.

FAO. (2007). State of the world's forests. Rome: FAO.

Ghimire, K. B. \& Pimbert, M. B. (1997). Social Change and Conservation Environmental Politics and Impacts of National Parks and protected areas. London: UNRISD and Earthscan.

Gomez-Pompa, A. \& Burley, F. W. (1991). The management of Natural Tropical Forests" in Gomez-Pompa, A. (eds) Rainforest Regeneration and Management, Man and the Biosphere series, 3-17, New Jersey.

Headley, M. (2003). Participatory Forest Management: The Jamaca Forestry Department Experience. UNASYLVA, 54, 214/215.

Joshi, A. L. (1996). Community Forest in Nepal. Paper presented at the fifth Asia Forestry Networks, Surajkund, India.

Kemp, R. H., Namkoong, G. \& Wadsworth (1993). Conservation of Genetic Resources in Tropical Forest Management: Principles and concepts, Rome: FAO.

Kothari, A., Anuradha, R. V. \& Pathak, N. (1998). Community-based Conservation: Issues and prospects. In Ashish, K., Pathak, N, Anuradha, R. V. and Taneja, B. (eds). Communities and conservation: Natural Resource Management in South and Central Asia. (pp. 25-27), New Delhi: Sage Publisher.

National Research Council. (1993). Sustainable Agriculture and the Environment in the Humid Tropics, Washington DC: National Academy Press.

Ogar, D. A. (2001). Impacts of Forest and some Non-forest Policies on Deforestation, South Eastern Nigeria, unpublished Ph.D. Thesis. Ibadan: University of Ibadan.

Pande, P. Kothari, A., Singh, S., et al. (1989). Management of National Parks and Sanctuaries in India: A Status report. New Delhi: India Institute of Public Administration. 
Raufflet, E. \& Barragan, P. M. (2006). Organizational dimension of decentralized forest management: lessons from a farmers' co-operative in central Mexico. UNASYLVA, 57(223), 22-27.

Saberwal, V. (1996). Pastoral politics: Gaddi grazing, degradation and biodiversity conservation in Himachal Pradesh. Conservation Biology, 10(3), 741-747. http://dx.doi.org/10.1046/j.1523-1739.1996.10030741.x

Schreckenberg, K. \& Hadley, M. (1991). Economic and Ecological sustainability of tropical rainforest management. UNESCO, France.

Scott, J. C. (1996). Seeing like a state: how certain modern schemes to improve human conditions have failed. Yale University Press, 19, 229-244.

Ubi, S. (2007). Afi mountain wildlife sanctuary: The challenges of conservation. Newsletter, 3, 3.

Udofia, P. E. (2006). Fundamental of Social Science Statistics. Uyo: Immaculate Pub. Ltd.

Waggener, T. R. (2004). Role of plantains as substitute for natural Forests in wood supply-lessons from the Asia -pacific region in Romco, F.A. (eds) Smallholders and communities in plantation development lessons from two ITTO- supported project, Nueva Viscaya.

West, P. C. \& Brechin, S. R. (1991). Resident people and National parks: Social Dilemnas and strategies in International Conservation. Tucson: University of Amazons press.

Western, D. \& Wright, R. M. (1994). National Connections: Perspectives in Community-based Conservation. Washington DC: Island Press.

Worldwide Fund for Nature. (1993). African Biodiversity: Foundation for the Future. Beltsville: Maryland Professional printing Inc.

Table 1. Percentage of tropical high forest cover in the study area

\begin{tabular}{|c|c|c|c|c|c|c|}
\hline LGA & High forest & $\begin{array}{c}\text { Swamp } \\
\text { forest }\end{array}$ & $\begin{array}{c}\text { Mangrove } \\
\text { forest }\end{array}$ & Other forest & $\begin{array}{c}\text { Other } \\
\text { landuse }\end{array}$ & $\begin{array}{c}\text { Total area } \\
\left(\mathrm{km}^{2}\right)\end{array}$ \\
\hline Akamkpa & 78 & 0 & 0 & 6 & 16 & 4,940 \\
\hline Biase & 14 & 3 & 0 & 5 & 77 & 1,290 \\
\hline Boki & 66 & 0 & 0 & 1 & 33 & 2,740 \\
\hline Ikom/Etung & 39 & 0 & 0 & 5 & 56 & 2,740 \\
\hline Obanliku & 3 & 0 & 0 & 0 & 97 & 1,060 \\
\hline Obubra & 15 & 0 & 0 & 5 & 80 & 520 \\
\hline Obudu & 2 & 0 & 0 & 0 & 98 & 520 \\
\hline Yakurr & 22 & 0 & 0 & 3 & 75 & 670 \\
\hline Total & 29.88 & 0.33 & 0 & 3.13 & 66.5 & 1806.25 \\
\hline
\end{tabular}

Source: Culled from Dunn, Otu and Wong, 1994

Table 2. Forest Types and Sizes in the Study area

\begin{tabular}{|c|c|c|}
\hline Forest Areas & Sizes (in hectares) & Percentages (\%) \\
\hline Okwango Division of National park & $174,489.03$ & 18.93 \\
\hline Oban Division of National Park & $331,812.58$ & 36 \\
\hline Forest reserves & $206,290.25$ & 22.38 \\
\hline Community protected forest & $209,114.70$ & 22.69 \\
\hline Total & $921,706.56$ & 100 \\
\hline
\end{tabular}

Source: culled from Ajake, 2008 
Table 3. Household Responses to Effectiveness of Forest Management institutions in Cross River State

\begin{tabular}{|c|c|c|c|}
\hline Sampled communities & Government institutions & Community institutions & NGOs \\
\hline Agbokim & 20 & 50 & 8 \\
\hline Ajassor & 26 & 42 & 12 \\
\hline Akparabong & 42 & 166 & 20 \\
\hline Okuni & 70 & 135 & 18 \\
\hline Abo Ebam & 12 & 39 & 6 \\
\hline Orimenkpang & 20 & 32 & 4 \\
\hline Odonget & 14 & 59 & 7 \\
\hline Iyametet & 24 & 122 & 9 \\
\hline Agoi Ekpo & 8 & 102 & 8 \\
\hline Ibami & 7 & 90 & 10 \\
\hline Ibogo & 18 & 42 & 4 \\
\hline Idoma & 10 & 32 & 3 \\
\hline Iko Ekperem & 13 & 65 & 9 \\
\hline Iwuru central & 10 & 59 & 2 \\
\hline Bayatong & 11 & 28 & 7 \\
\hline Okorshie & 14 & 36 & 9 \\
\hline Bendi II & 6 & 32 & 2 \\
\hline Busi I & 5 & 36 & 3 \\
\hline Total & 336 & 1,167 & 141 \\
\hline Mean & 18.66 & 64.83 & 7.83 \\
\hline Percentage (\%) & $(20.44 \%)$ & $(70.95 \%)$ & $(8.58 \%)$ \\
\hline
\end{tabular}

Source: Author's Field work, 2010

Table 4. Assessment of Forest Management Institution and their Initiatives in the area

\begin{tabular}{|c|c|c|c|c|c|}
\hline Management Initiatives & Government & Community & NGOs & Total & $\%$ \\
\hline Forest law/Regulation & $30(46.15 \%)$ & $35(53.85 \%)$ & $0(0 \%)$ & 65 & 15.46 \\
\hline Forest Advocacy & $12(17.14 \%)$ & $(31.43 \%)$ & $36(51.43 \%)$ & 70 & 16.20 \\
\hline Forest Reservation & $20(37.04 \%)$ & $40(34(62.96 \%)$ & $0(0 \%)$ & 54 & 12.5 \\
\hline Harvesting techniques & $30(36.61 \%)$ & $40(40.82 \%)$ & $28(28.57 \%)$ & 98 & 22.69 \\
\hline Empowerment & $10(20.83 \%)$ & $18(37.5 \%)$ & $20(41.67 \%)$ & 48 & 11.11 \\
\hline Capacity building & $5(12.15 \%)$ & $8(34.24 \%)$ & $20(60.61 \%)$ & 33 & 7.64 \\
\hline Monitoring programmes & $5(20 \%)$ & $20(80 \%)$ & $0(0 \%)$ & 25 & 5.79 \\
\hline Others & $8(20.51 \%)$ & $25(64.70 \%)$ & $6(15.38 \%)$ & 39 & 9.03 \\
\hline Total & 120 & 202 & 110 & 432 & 100 \\
\hline Mean & 15 & 25.25 & 13.75 & 54 & \\
\hline$\%$ & $27.78 \%$ & $46.76 \%$ & 25.46 & 100 & \\
\hline
\end{tabular}

Source: Author's field work, 2010 
Table 5. Analysis of Variance of Forest Management Institutions in the Area

\begin{tabular}{|c|c|c|c|c|c|}
\hline Source of variance & Sum of squares & DF & Mean square & F & Tabulated F-value \\
\hline Between Groups & 33129.00 & 2 & 16564.50 & & \\
\hline Within Groups & 33309.00 & 51 & 653.12 & 25.362 & 3.32 \\
\hline Total & 66438.00 & 53 & & & \\
\hline
\end{tabular}

Significant at 0.05 level of confidence

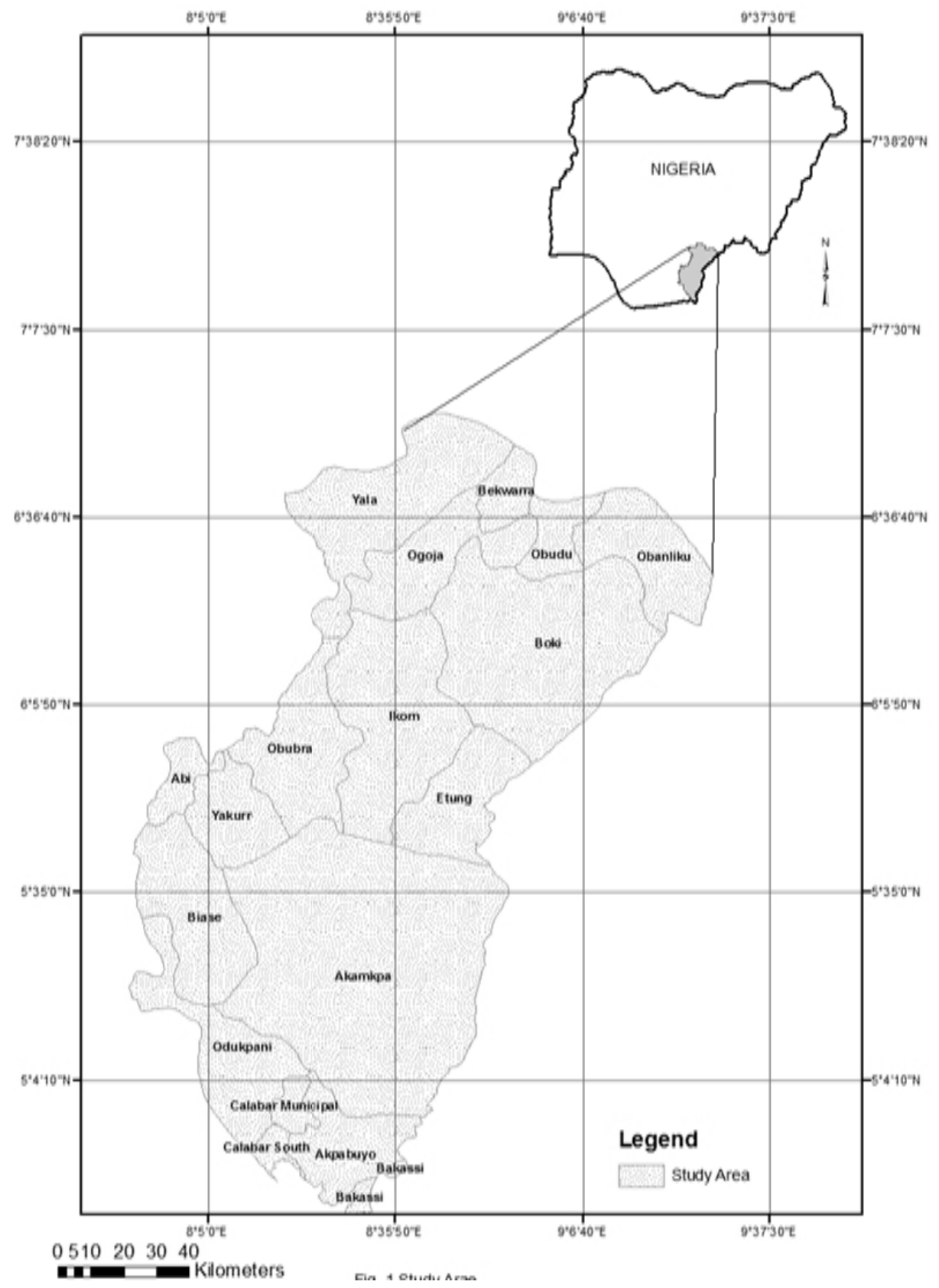

Figure 1. Study Area 